\title{
Satisfaction of Old Graduates of Zootechnical Engineering for Improvement of Educational Quality at the UNCP
}

\author{
Jorge Castro-Bedriñana ${ }^{*}, 1$, Doris Chirinos-Peinado ${ }^{1}$, Felipe Zenteno-Vigo ${ }^{1}$, Gianfranco Castro-Chirinos ${ }^{2}$ \\ ${ }^{1}$ Faculty of Zootechnics, Universidad Nacional del Centro del Perú, Huancayo, Perú \\ ${ }^{2}$ Faculty of Psychology, Universidad Peruana de Ciencias Aplicadas, Perú
}

\begin{tabular}{l} 
A R T I C L E I N F O \\
\hline Article history: \\
Received: 26 December, 2016 Accepted: 22 February, 2020 \\
Online: 09 March, 2020 \\
\hline Keywords: \\
Curriculum \\
Old graduate \\
Graduate satisfaction \\
Continuous improvement \\
Graduation profile \\
Competence approach \\
Professional performance \\
Curriculum update \\
Zootechnics program
\end{tabular}

\section{Introduction}

Universal access to higher education is a global commitment and is intended to minimize social inequality gaps [1], to contribute to scientific, technological and economic progress population [2]; for this, higher education institutions must be recognized for sustained quality assurance, self-regulation and relevant and efficient provision of their educational services [3]. In this context, to guarantee the satisfaction of the needs and expectations of students, graduates and interest groups, governments must monitor the quality of higher education through different strategies, which in Peru is carried out by the National System for the Evaluation, Accreditation and Certification of Educational Quality - Sineace, whose accreditation model for university programs sets 34 quality standards [4].

\footnotetext{
*Jorge Castro-Bedriñana, Av. Mariscal Castilla N 3909, El Tambo-Huancayo.

+51964408057.jorgecastrobe@yahoo.com
}

Demand for quality educational services not only comes from students satisfied with their training and educational services received, but from their parents or caregivers who cover educational expenses [5], and satisfaction of interest groups and employers; Therefore, the labor insertion of graduates and the achievement of educational objectives are monitored after 3 years of professional experience [6], to demonstrate the relevance of professional training with the needs of the environment and social demand [7].

A quality training process allows graduates to meet labor demand with high levels of satisfaction; therefore, the quality of higher education is reflected in the quality of its graduates [8], with full achievement of competencies defined in its profile [6].

The quality factors that evaluate comprehensive training are linked to the teaching-learning process, and consider 4 quality standards, with their indicators [6]: 


\section{J. Castro et al. / Advances in Science, Technology and Engineering Systems Journal Vol. 5, No. 2, 166-173 (2020)}

- Curriculum: input profile and graduation profile with a focus on competencies, with general, basic and specialized areas, teaching strategies, relevance, evaluation and periodic updating.

- Teaching-learning process: articulate learning with research, development and innovation (RDi) and social responsibility with the participation of students and teachers; mobility agreements and exchange of experiences.

- Teacher management: adequate selection, evaluation, training and improvement, recognition and stimulation of teaching activity and intellectual production.

- Follow-up to students: adequate selection of new students, leveling programs to start and extracurricular activities that contribute to their training.

To assess achievement of competence and employability, representative information should be measured and collected to strengthen the teaching-learning process and update the curriculum, the graduation profile, improve teacher management and other related processes [6]. The satisfaction evaluation of graduates with different services offered by the university and its curriculum, in recent years have intensified in the search for the quality and excellence of higher education $[9,4]$.

It is necessary that university training programs analyze and reflect on their current situation and their environment, and redefine their purpose through dialogue with different interest groups, including graduates, to know their perceptions and expectations, in order to improve educational quality [10].

In major universities in the world, information about graduates is collected through surveys $[11,12,13]$. In Peru, all accredited university programs conduct follow-up surveys of their graduates, monitoring employability and fulfillment of educational objectives or career purposes [14].

Regarding careers linked to agriculture, the Inter-American Institute for Cooperation on Agriculture (IICA), as a result of Regional Meetings for the Modernization of Agricultural Sciences Faculties, more than two decades ago suggests improving the link with the environment [15], considering the scientific progress, technological, socio-economic and cultural changes, that today added to a context of climate change. Recent study by SineacePeru, called "Training offer and labor demand of technical and professional personnel in risk and disaster management and climate change", reveals that professional needs are directed to specialists who make climate change effects more bearable; Higher education institutions must shape their academic proposals in agricultural, environmental, biological and health careers [16].

Profiles of graduation from Zootechnical Faculties must guarantee the formation of transformative and integral human potential, which contributes to solve problems that delay the progress of family agri-food production and medium and largescale production systems. Rural population requires appropriate production technologies to contribute to their food security [17], and on the other hand export agriculture should be intensified, as the country's fundamental economic livelihood, through the generation of modern technology for sustainable production and minimizing pollution environmental. This context demands radical changes in the curriculum to improve critical thinking, with soft skills, knowledgeable about their environment, with investigative and innovation skills, committed to producers and accompany them in their development, with social responsibility.

In the Faculty of Zootechnics of UNCP, since its foundation in 1959, various curricula characterized by their linearity and minimum flexibility were applied [18]. In this context, the research objective was to determine the graduates satisfaction level, trained with curricula 1979, 1985 and 1995 who have more than 20 years of graduation from Zootechnical Faculty of the Universidad Nacional del Centro del Perú (UNCP), the main deficiencies perceived by graduates in curriculum development, areas of knowledge that should be reinforced and the reasons for dissatisfaction.

Research is structured as follows: Section 2 presents the methodology used in this study; descriptive and relational methodology, determining the correlation of evaluated variables. Section 3 shows the results obtained after conducting surveys. Section 4 presents the discussion of results and conclusions.

\section{Material and method}

\subsection{Type and level of research}

Cross-sectional, descriptive and relational study.

\subsection{Sample framework for graduate satisfaction survey}

Survey was carried out to 60 graduates in professional activity for more than 20 years; $28.3 \%$ were formed with the 1979 curriculum, $40.0 \%$ with the 1985 curriculum and $31.7 \%$ with the 1995 curriculum. Sampling was systematic probabilistic, which is very efficient when there are a limited number of subjects with the same qualities as the target population [19], in this case, old graduates of the Faculty of Zootechnics - UNCP.

\subsection{Collection of information and measuring instruments survey}

The information was collected by applying a semi-structured survey at a meeting of graduates, who studied with the curricula of 1979, 1985 and 1995.

The survey instrument considered general information on the date of graduation, the curriculum followed $(1979,1985$ or 1995) and the highest academic degree. Specific information considered the perception about employability, work area, areas to reinforce the profile, qualification criteria of the study curriculum, curricular deficiencies, satisfaction level with the curricular consistency, and suggestions to reinforce the curriculum.

\subsection{Statistical analysis}

Statistical analyzes were performed with SPSS 23, generating univariate descriptive results. Bivariate and multivariate correlations were also determined between the variables linked to the perception of graduates regarding their curricula followed during professional training.

\section{Results}

Figures 1 to 4 show information on the number of respondents by curriculum, the highest academic degree obtained, employment level and professional work area.

More than $50 \%$ of graduates have obtained the professional title by thesis modality and only one had a Doctor degree (Figure 
2). The majority work in public institutions, highlighting temporary jobs in areas other than zootechnics (Figure 3). Less than half work in activities related to animal production, animal health, livestock unit management, agricultural marketing, teaching and consulting in the agricultural area (Figure 4).

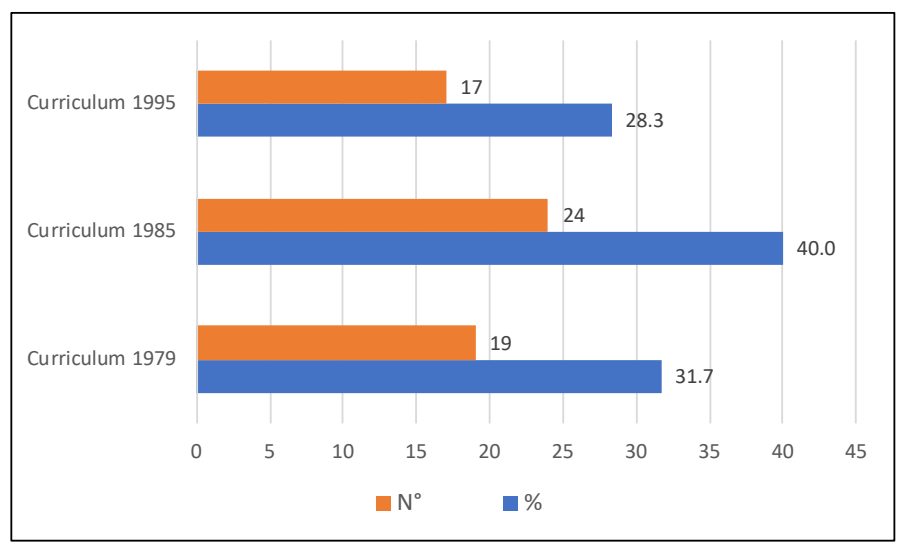

Figure. 1 Graduates who participated in the survey

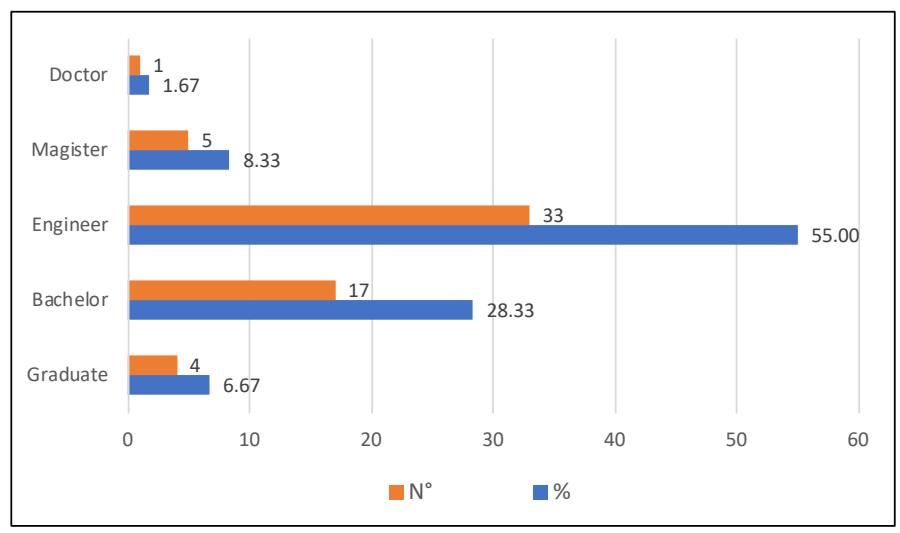

Figure 2. Highest grade of respondents

Figures 5 to 10 show the results of the areas of reinforcement suggested by the graduates, curriculum qualification and factors considered, suggestions for curriculum type, graduate achievements and the perception of curriculum relevance. Main five areas that graduates suggest strengthening in the curricula are strategic planning, social evaluation of investment projects, biotechnology and genetic engineering, livestock management, and budget and financing (Figure 5).

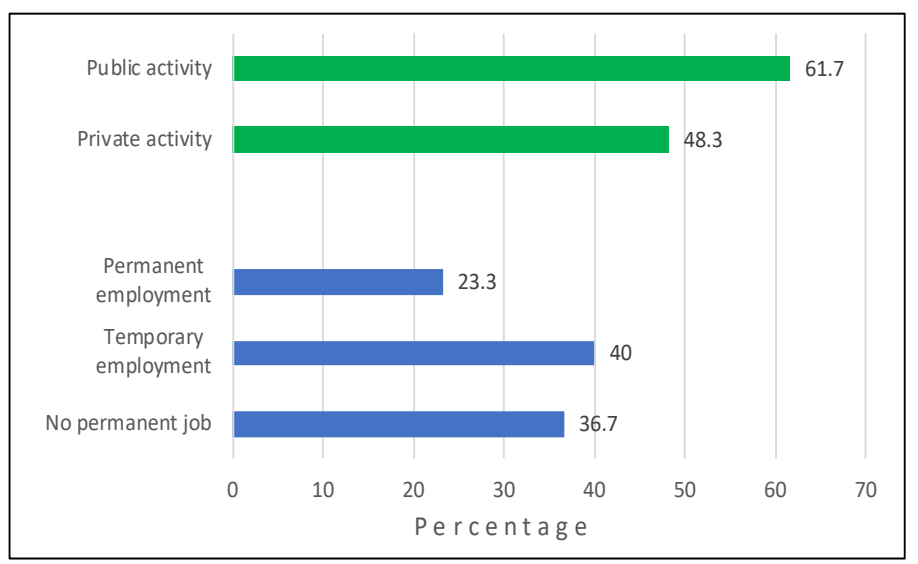

Figure 3. Employability of graduates

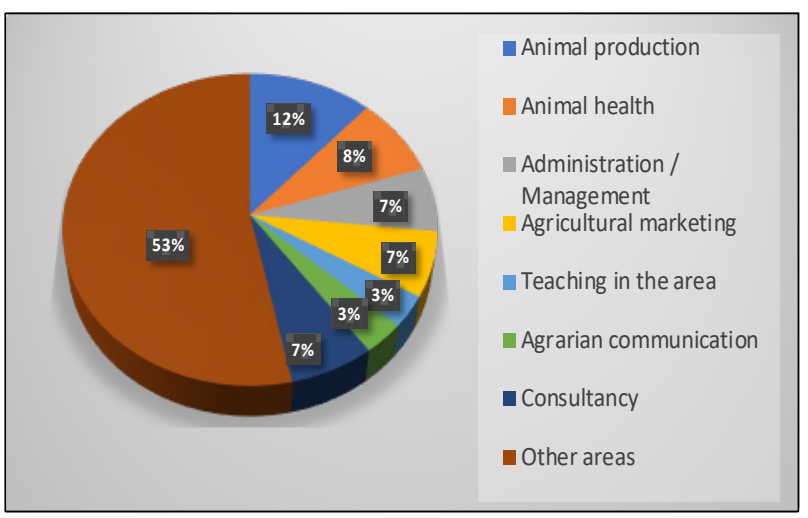

Figure 4. Graduates work area

Regarding the curriculum qualification, the majority consider "Regular" (Figure 6), and for improvement, additionally to consider areas to be reinforced, they suggest the development of modular or block curricular experiences; that is, by competencies (Figure 7). Additionally, for adequate curriculum development and guaranteeing the achievement of competencies, the program must establish strategies to improve the academic and research level of teachers (Figure 8). They consider having received an adequate theoretical basis and the practical aspects must be reinforced (Figure 9); For these reasons, the graduates of the study have perceived that the curriculum had little relevance (Figure 10).

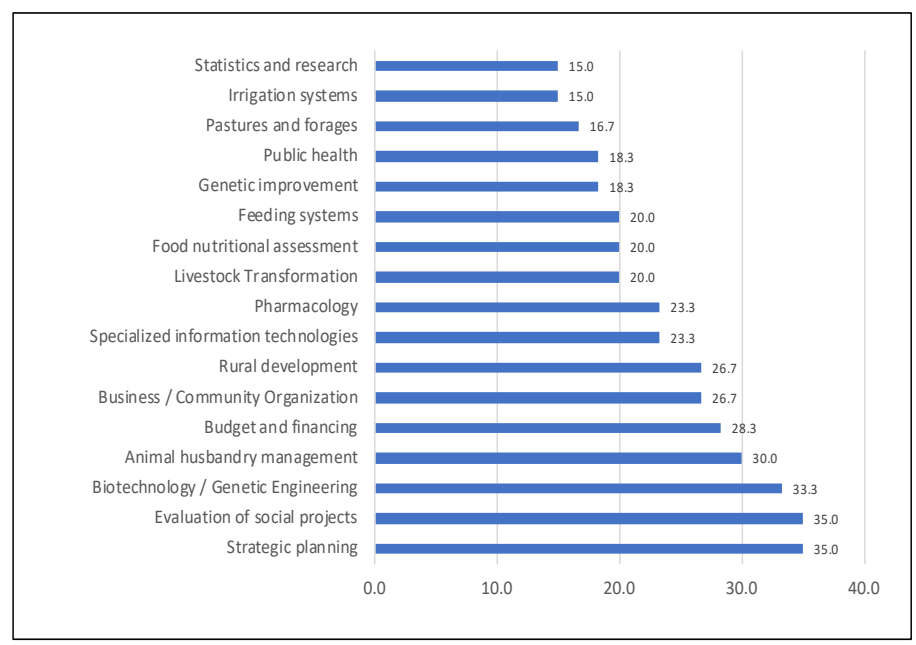

Figure 5. Areas to reinforce profile

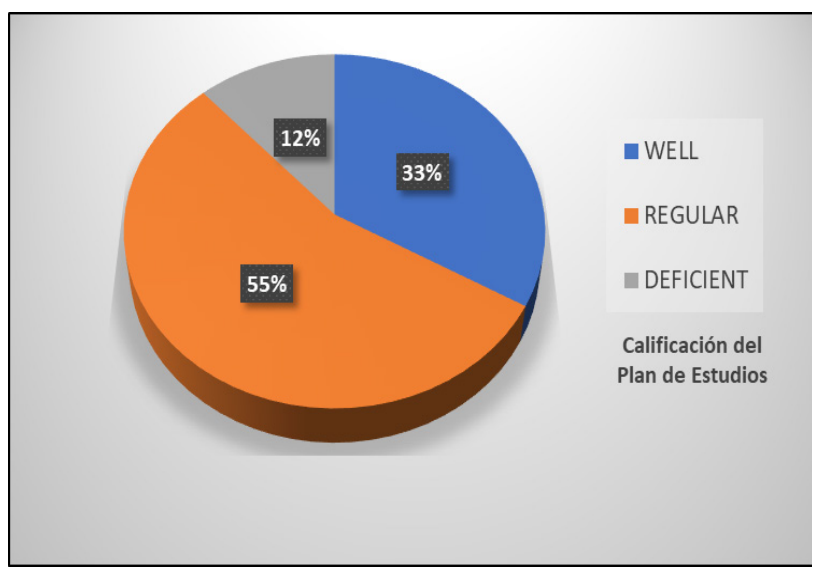

Figure 6. Qualification of the Curriculum by graduates 


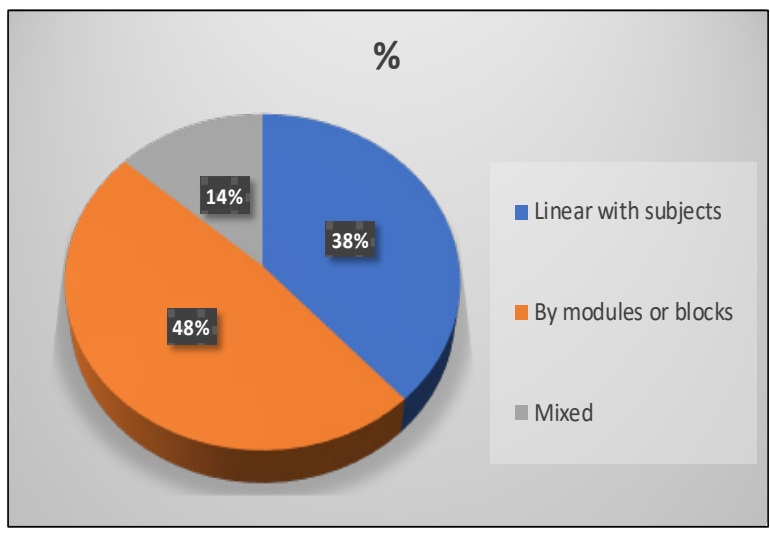

Figure 7. Suggestion of graduates to modify the Curriculum

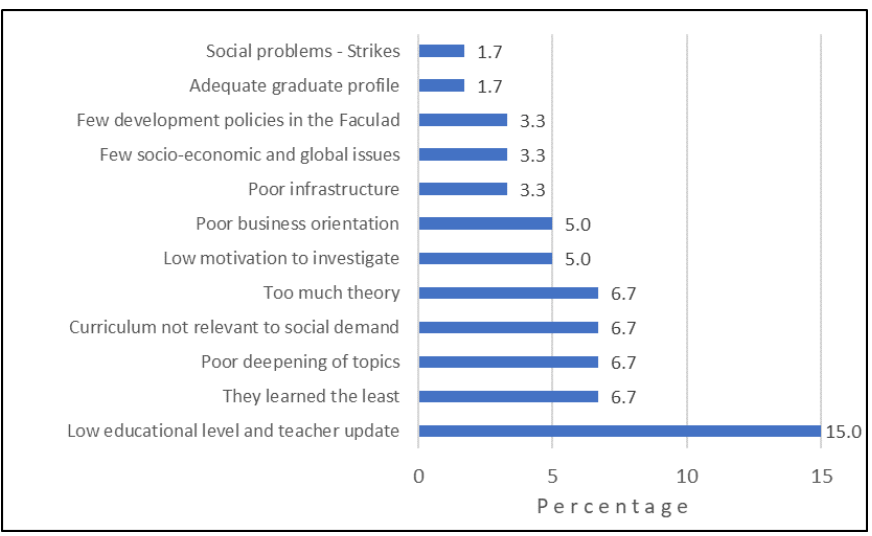

Figure 8 . Factors considered to qualify the curriculum

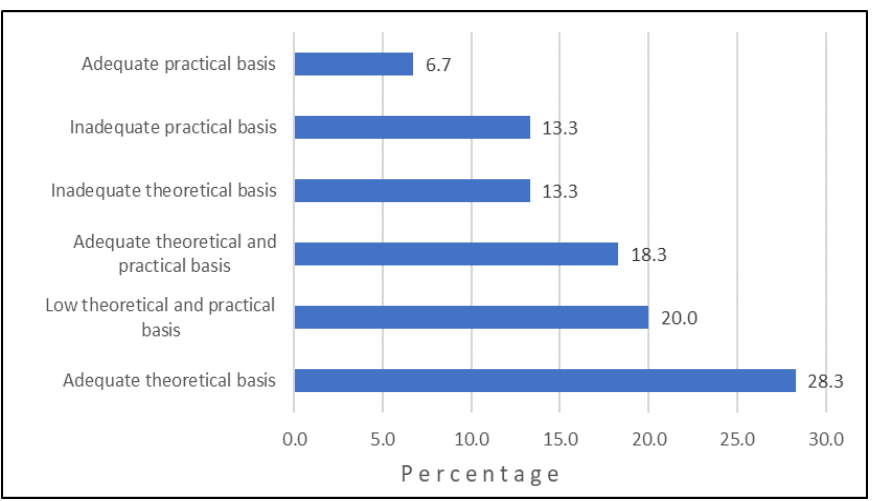

Figure 9. Achievements of graduates with a corresponding curriculum

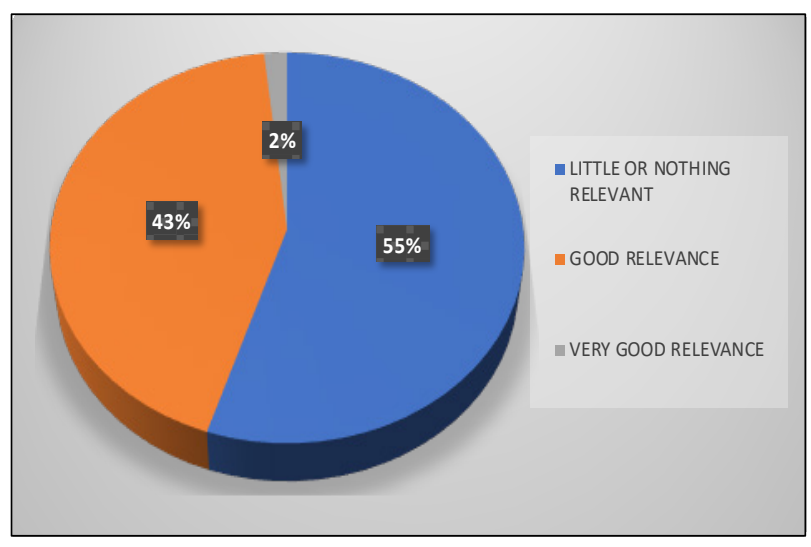

Figure 10. Relevance of the curriculum
The satisfaction level with professional training was $46.7 \%$ and not satisfied was $53.3 \%$. Respect to specialized knowledge received, $23.3 \%$ was enough, $58.3 \%$ was not enough, and $18.3 \%$ was insufficient.

Figures 11 and 12 show the percentage of the main reasons for dissatisfaction in professional training and the perception of curricular deficiencies.

Among the main reasons for dissatisfaction with professional training they indicate having had non-innovative and outdated teachers, inappropriate graduation profile, and in the professional practice they do not apply everything they learned (Figure 11).

Graduates perceive that the main deficiencies in the curriculum are due to the superficial and outdated knowledge received during professional training, with priority cognitive curricular experiences.

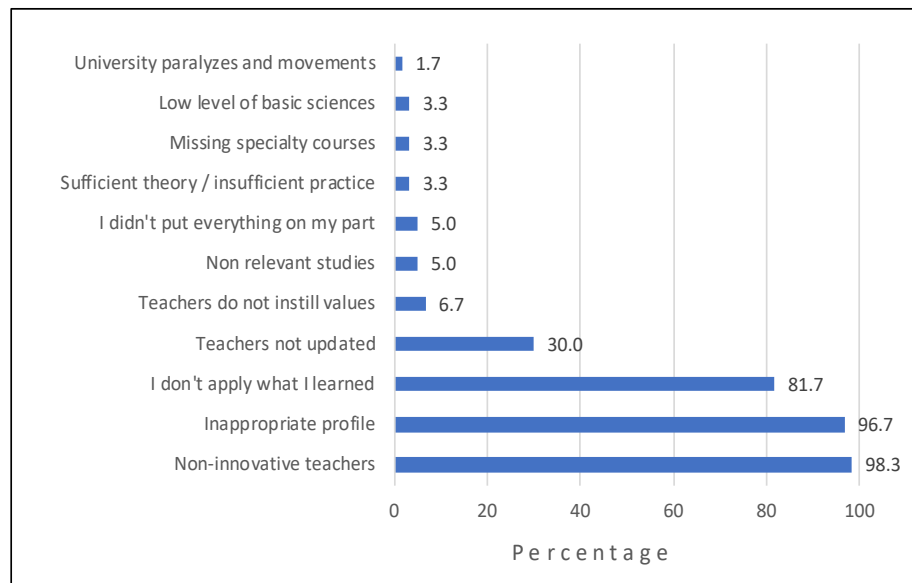

Figure 11. Main reasons for dissatisfaction in professional training

To determine the correlation that exists between some variables considered in the perception survey with curricula followed by graduates, it was considered: There is no correlation $=0$; Moderate positive correlation $=0.3$ to 0.5 ; Strong positive correlation $>0.5$; Perfect positive correlation $>1.0$.

Significant correlations were found between the variables linked to the perception of graduates regarding the curricula developed during professional training (Table 1).

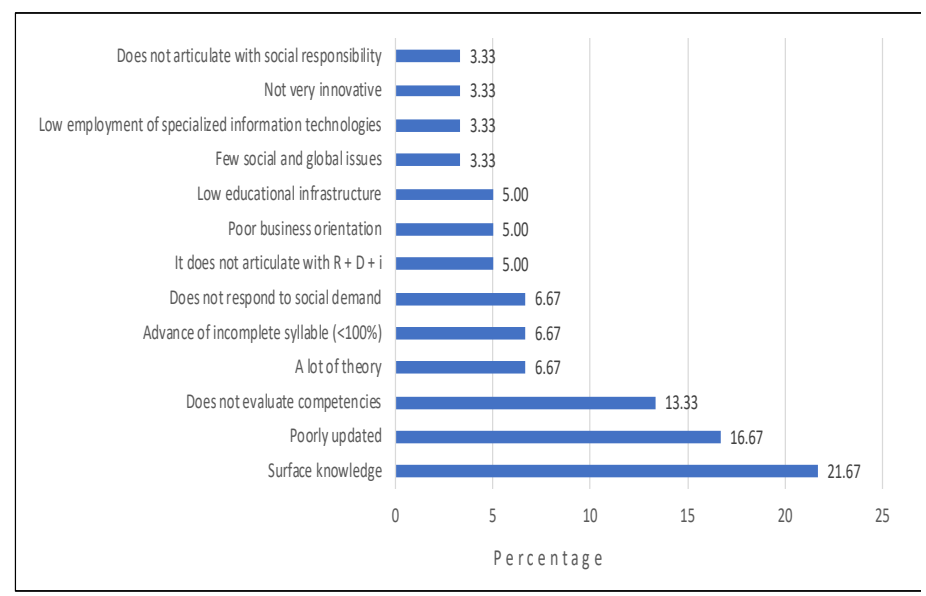

Figure 12. Perception of the curriculum deficiencies 
Table 1. Spearman's correlation between some variables that showed statistical significance $(P<0.05)$

\begin{tabular}{|c|c|c|c|}
\hline Variable 1 & Variable 2 & $\mathbf{r}$ & $\begin{array}{c}\text { p- } \\
\text { value }\end{array}$ \\
\hline $\begin{array}{l}\text { Professional status of the } \\
\text { grachuate }\end{array}$ & Cumiculum & 0.434 & 0.001 \\
\hline $\begin{array}{l}\text { Professional status of the } \\
\text { graduate }\end{array}$ & Where you currently work & 0.736 & 0.000 \\
\hline $\begin{array}{l}\text { Professional status of the } \\
\text { graduate }\end{array}$ & Main Work Area & 0.725 & 0.000 \\
\hline Cumiculum relevance & Expand wock areas & 0.333 & 0.009 \\
\hline $\begin{array}{l}\text { Strengthen diagnostic } \\
\text { knowiedge }\end{array}$ & $\begin{array}{l}\text { Strengthen knowledge in } \\
\text { budget and financing }\end{array}$ & 0.406 & 0.001 \\
\hline $\begin{array}{l}\text { Strengthen diagnostic } \\
\text { knowiledge }\end{array}$ & $\begin{array}{l}\text { Strengthen knowledge in } \\
\text { business / community } \\
\text { organization }\end{array}$ & 0.435 & 0.001 \\
\hline $\begin{array}{l}\text { Strengthen diagnostic } \\
\text { knowiedge }\end{array}$ & $\begin{array}{l}\text { Strengthen hrowledge in data } \\
\text { analysis and interpretation }\end{array}$ & 0.453 & 0.000 \\
\hline $\begin{array}{l}\text { Strengthen diagnostic } \\
\text { knowiedge }\end{array}$ & $\begin{array}{l}\text { Strengthen conputer and } \\
\text { informatic lmoviledge }\end{array}$ & 0.319 & 0.013 \\
\hline $\begin{array}{l}\text { Strengthen hrowledge in } \\
\text { budget and financing }\end{array}$ & $\begin{array}{l}\text { Strengthen strategic plaming } \\
\text { knowledge }\end{array}$ & 0.469 & 0.000 \\
\hline $\begin{array}{l}\text { Strengthen knowledge in } \\
\text { business / community } \\
\text { organization }\end{array}$ & $\begin{array}{l}\text { Strengthen knowledge in } \\
\text { technology transfer }\end{array}$ & 0.485 & 0.000 \\
\hline $\begin{array}{l}\text { Strengthen hrowledge in } \\
\text { reproduction systems }\end{array}$ & $\begin{array}{l}\text { Surengthen hrowledge in } \\
\text { feeding systems }\end{array}$ & 0.515 & 0.000 \\
\hline $\begin{array}{l}\text { Strengthen hwowledge in } \\
\text { reproduction systems }\end{array}$ & $\begin{array}{l}\text { Strengthen knowledge in } \\
\text { balanced ration fonmulation }\end{array}$ & 0.523 & 0.000 \\
\hline $\begin{array}{l}\text { Strengthen knowledge in food } \\
\text { mutritional assessment }\end{array}$ & $\begin{array}{l}\text { Strengthen knowledge in } \\
\text { balanced ration fonmulation }\end{array}$ & 0.528 & 0.000 \\
\hline $\begin{array}{l}\text { Strengthen krowledge in food } \\
\text { mutritional assessment }\end{array}$ & $\begin{array}{l}\text { Strengthen hrowiledge in } \\
\text { prevention awd promotion of } \\
\text { animal health }\end{array}$ & 0.467 & 0.000 \\
\hline $\begin{array}{l}\text { Strengthen knowledge in } \\
\text { animal husbundy namagement }\end{array}$ & $\begin{array}{l}\text { Strengthen knowledge in } \\
\text { feecing systems }\end{array}$ & 0.395 & 0.006 \\
\hline $\begin{array}{l}\text { Strengthen knowledge in } \\
\text { balanced ration formulation }\end{array}$ & $\begin{array}{l}\text { Strengthen knowledge in } \\
\text { technology transfer }\end{array}$ & 0.571 & 0.000 \\
\hline $\begin{array}{l}\text { Strengthen knowledge in } \\
\text { balanced food processing }\end{array}$ & $\begin{array}{l}\text { Strengthen knowiledge in } \\
\text { technology transfer }\end{array}$ & 0.621 & 0.000 \\
\hline $\begin{array}{l}\text { Strengthen knowledge in } \\
\text { balanced food processing }\end{array}$ & $\begin{array}{l}\text { Strengthen krowiledge in } \\
\text { animal husbanchy } \\
\text { management }\end{array}$ & 0.492 & 0.000 \\
\hline $\begin{array}{l}\text { Strengthen lnowiledge of } \\
\text { cultivation and nanagement of } \\
\text { pastures and forages }\end{array}$ & $\begin{array}{l}\text { Strengthen kxowiledge in } \\
\text { technology transfer }\end{array}$ & 0.395 & 0.002 \\
\hline $\begin{array}{l}\text { Strengthen hnowledge in } \\
\text { education and agricultural } \\
\text { communication }\end{array}$ & $\begin{array}{l}\text { Strengthen knowledge in } \\
\text { technology transfer }\end{array}$ & 0.515 & 0.000 \\
\hline $\begin{array}{l}\text { Strengthen knowledge in rural } \\
\text { development }\end{array}$ & $\begin{array}{l}\text { Strengthen knowiledge in soil } \\
\text { mansigement }\end{array}$ & 0.416 & 0.000 \\
\hline $\begin{array}{l}\text { Strengthen knowledge in } \\
\text { irigation systems }\end{array}$ & $\begin{array}{l}\text { Strengthen knowledge in } \\
\text { silvopastoral management }\end{array}$ & 0.522 & 0.000 \\
\hline
\end{tabular}

Between Spearman's correlations that showed statistical significance $(P<0.05)$, the professional situation of the graduate with the relevance of the curriculum, and with the place and area of work stands out [16]; observing greater economic benefits when better professional training was received (Table 1).

There is also a series of relationships between different subjects or issues, which demonstrate synergy and must be organized in the correct sequence, establishing an appropriate curriculum mapping with basic competencies as a requirement of specific competences [6].

The solar projection graph represents hierarchical data as concentric rings in a circle; the correlation values (r) have been coded as arcs within each ring. Each level of the hierarchy is represented by a ring or circle, the inner circle being the top of the hierarchy (Figure 13).

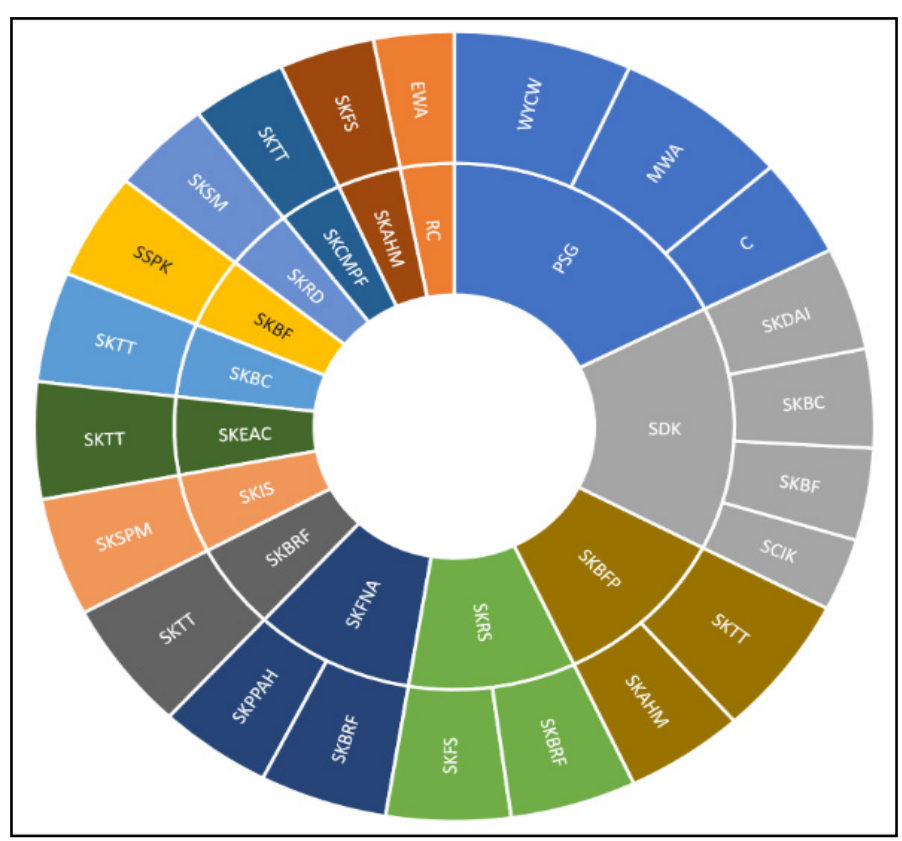

Figure 13. Solar projection of hierarchically coded correlations

C: Curriculum, EWA: Expand work areas, MWA: Main Work Area, PSG: Professional status of the graduate, RC: Curriculum relevance, SCIK: Strengthen computer and informatic knowledge, SDK: Strengthen diagnostic knowledge, SKAHM: Strengthen knowledge in animal husbandry management, SKBC: Strengthen knowledge in business / community organization, SKBF: Strengthen knowledge in budget and financing, SKBFP: Strengthen knowledge in balanced food processing, SKBRF: Strengthen knowledge in balanced ration formulation, SKCMPF: Strengthen knowledge of cultivation and management of pastures and forages, SKDAI: Strengthen knowledge in data analysis and interpretation, SKEAC: Strengthen knowledge in education and agricultural communication, SKFNA: Strengthen knowledge in food nutritional assessment, SKFS: Strengthen knowledge in feeding systems, SKIS: Strengthen knowledge in irrigation systems, SKPPAH: Strengthen knowledge in prevention and promotion of animal health, SKRD: Strengthen knowledge in rural development, SKRS: Strengthen knowledge in reproduction systems, SKSM: Strengthen knowledge in soil management, SKSPM: Strengthen knowledge in silvopastoral management, SKTT: Strengthen knowledge in technology transfer, SSPK: Strengthen strategic planning knowledge, WYCW: Where you currently work.

\section{Discussion}

Research examines the satisfaction and experiences of graduates of the Zootechnical Faculty of UNCP with your professional training and the recommendations given to strengthen the curriculum and improve professional performance in the context of globalization, based on curricular experiences with 1979, 1985 and 1995 plans. This document contributes to knowledge in the field of quality assurance of higher education services [7].

In this study, the "Good" qualification of the curriculum is mainly based on the fact that graduates learned the minimum and regularly work in the profession. The "Regular" qualification responds to too much theory, and lack of practices, poor laboratory infrastructure, farms, classrooms, audiovisual equipment, agricultural equipment and tools, poor motivation to research and innovate, poor business orientation, superficiality in developed topics, low academic level teacher, poor teaching methodology, poor updating, incomplete syllable development, lack of socioeconomic issues, lack of faculty development policies, low relevance of curriculum, and low engineering level that leads to problems of professional development. 


\section{J. Castro et al. / Advances in Science, Technology and Engineering Systems Journal Vol. 5, No. 2, $166-173$ (2020)}

The "Poor" curricular qualification is directly related to the problems identifies in the Zootechnics study program [20], indicating that the graduates are not formed in basis to require for the development for Peruvian agriculture; They have little insertion in the labor market, the quality of their training does not meet the requirements of employers. They have little capacity for entrepreneurship and commitment to the environment. These results force to carry out a curricular reform to move to teaching with a competency approach, in order to comply with standards of accreditation of university careers considered in the National System of Accreditation and Certification of Educational Quality of Peru $[4,6]$, redesigning the graduation profile that considers general and specific competences $[21,4,6]$.

Regarding curricular relevance, the majority of respondents say that it does not respond to the needs of local and national reality, and should be modified in response to social demand and have a new professional with solid humanistic, scientific and technological training, with training capacity continuous, with comprehensive training and with social and environmental responsibility; processes in which authorities, teachers, students, graduates and properly identified interest groups must participate $[4,6]$.

Information of graduates is an important source of feedback for the study program and the university. The connection with the labor market contributes to the development of university social responsibility, and is a bridge between university and social context [22], determining the social role, positioning and relevance [23].

Monitoring graduates offers evidence for curriculum reform. The professional and personal performance of graduates allows identifying quality and efficiency indicators of higher education institutions [24].

The results of the study indicate that more than half of the graduates of the faculty of zootechnics UNCP, who studied with the curricula 1975, 195 and 1995 do not work in activities related to zootechnics (Figure 4), relevant aspect of the study, linked to the non-fulfillment of educational objectives of a public university [6]. Training professionals who do not work in your area means a loss to the State and society; and it is suggested to prioritize a comprehensive curriculum reform.

Information from graduates on educational quality, job placement and other characteristics facilitates the development of strengths and implementation of improvement plans for higher education institutions $[25,26]$. Evaluation of satisfaction with academic and administrative services received in training is a right of graduates [27] and can be carried out through end of training surveys [28] and follow-up surveys after 3 or more years of professional practice [6]. In state institutions it is directly related to accountability to society, not only for the purpose of management transparency, but to demonstrate a quality educational service [29].

In this study, satisfaction of graduates is well below medical graduates of the Cienfuegos University of Cuba, where more than $80 \%$ of respondents expressed their satisfaction with the promotion and consolidation of personal qualities, as well as in the training received for the professional performance [30], however, they showed dissatisfaction with regard to English language proficiency, new information and communication technologies, tutors and research advisors. A result similar to ours is dissatisfaction with the development of general or soft skills.

The improvement of university quality is not only caused by the increase in resources and infrastructure, but mainly by offering professionals trained and satisfied with the training received [31] and the information is needed to propose improvement plans. In this regard, the formative model by competences, seeks that the student relate theory to practice, which impacts on the achievement of professional competences [32].

Other studies on student satisfaction with curriculum content, teaching methods, infrastructure and facilities, teacher skills and student performance show that satisfaction levels are largely correlated with student academic performance, and with teacher skills [33] and with the teacher ability to interact with the students. The teacher's attitude excels in the student's interest [34].

Results show that graduates are satisfied with their training when they get a job in their professional area and in a suitable work place, with permanence of work. The ease of obtaining a job contributes to the appreciation of satisfaction and quality of the services received, and employers' satisfaction with the image and prestige of the higher institution that forms them $[35,36]$.

This study shows that the professional condition of the graduate is correlated with the relevance of the curriculum, place and work area (Table 1), aspects linked to the salary level [37, 38]. Engineers can earn more than social scientists, and these can earn more than teachers, but on average each will earn less if they are graduated from an institution of low selectivity and quality [39].

Graduates suggest strengthening knowledge in agricultural production systems, food security, public health and climate change, developing environmental awareness, synergistically integrating biotechnology and information technologies, having as transversal axes to RDi, and Social Responsibility, aspects which have to be prepared with the participation of interest groups $[4,6]$.

The general results of the study are similar to those of more than 20 years ago at the Universidad Nacional de Loja-Ecuador [40] who detected applicants and entrants without minimum knowledge for careers, with lacks of study and reading habits, without vocational guidance, with professional profiles without appropriate curricular research and not relevant, with archaic and traditional teaching systems, the master class and dictation subsisting, non-existence of a permanent system of curriculum evaluation, with memorized and fragmented learning, with evaluation based on exams, with insufficient implementation of laboratories and workshops, with outdated libraries, without research plans that allow the link between teaching, research and extension, with thesis without major scientific input and whose results were not disseminated. For these reasons they replaced the traditional educational model with a modular system that relates the university - society, integrating teaching, research and extension, around concrete problems of reality, implementing a modular academic system for transformation objects. The future of higher education was planned from the present, to face scenarios of high uncertainty and not easy to foresee [41], which implies new teaching-learning strategies, especially when university students 


\section{J. Castro et al. / Advances in Science, Technology and Engineering Systems Journal Vol. 5, No. 2, 166-173 (2020)}

currently have an amazing management of virtual technology, which must be included in the curriculum, without detriment to interpersonal contact, revaluing the emotional and social intelligences of the person [42].

Our results aim to improve the generation of science and technology from the university through the application of a properly designed curriculum, since agricultural education is an essential factor in the success of agricultural development in different countries [43] and linked university programs the agricultural sector must guarantee the training of professionals of quality and excellence [44].

\section{Conclusions}

The study determined the main weaknesses of the 1979, 1985 and 1995 curricula based on semi-structured surveys applied to old graduates of the professional program of Zootechnics - UNCP who have more than 20 years of work experience.

Satisfaction level of graduates regarding their curricula, in general, ranges from Regular to Poor.

The research offers elements of judgment to readjust the curriculum and train a new zootechnic engineer, required for the sustained development of the country.

It is recommended that managers, teachers, students, graduates and interest groups of the professional program of Zootechnics take into account the results of this study for reflections of curriculum reform.

\section{Limitations}

The conclusions of this study may have a limited generalized capacity for other zootechnical engineering programs, both in Peru and in other countries. The sample was intended to include all graduates of the Faculty of Zootechnics with the 1979, 1985 and 1995 curricula, but it was not possible for different places of current residences. The results should not be considered to characterize the relationship between the quality of the program and the job satisfaction of other universities due to the different environments. In this study, quality responds to the perceptions of graduates, which may vary based on relatively recent events in professional action and would have little to do with previous experiences in the academic career.

\section{Conflict of Interest}

The authors declare no conflict of interest.

\section{Acknowledgment}

To graduates who kindly gave their consent to participate in the survey, providing valuable contributions to be incorporated into the readjustment of the UNCP Zootechnics program curriculum.

\section{References}

[1] European Commission/EACEA/Eurydice (2013). Education and training in Europe 2020: Responses from the EU Member States. Eurydice Report; Brussels: $\quad$ Eurydice. https://op.europa.eu/en/publication-detail//publication/4cd55a97-854d-4fff-8ebd-3fd3f38ca58a/language-en. https://doi.org/10.2797/49490.

[2] Ali, F., Zhou, Y., Hussain, K., Nair, P. K., \& Ragavan, N. A. (2016). "Does higher education service quality effect student satisfaction, image and loyalty?: A study of international students in Malaysian public universities",
Quality Assurance in Education, Vol. 24 Issue: 1, pp.70-94, https://doi.org/10.1108/QAE-02-2014-0008.

[3] Nyagotti-Chacha, C. (2007). Public university, private funding: the challenges in East Africa. Higher Education in Postcolonial African Nations: Paradigm of Development, Decline, and Dilemmas.

[4] Sineace. (2016). Modelo de Acreditación para Programas de Estudios de Educación Superior Universitaria. Sistema Nacional de Evaluación, Acreditación y Certificación de la Calidad Educativa. Disponible en: https://www.sineace.gob.pe/wp-content/uploads/2014/08/Anexo-1-nuevomodelo-programas-Resolucion-175.pdf

[5] Rajab, A., Panatik, S. A., Rahman, A, Rahman, H. A., Shaari, R. \& Saat, M. (2011). Service quality in a research university: A postgraduate perspective. Procedia - Social and Behavioral Sciences 29 pp. 1830 - 1838. https://doi.org/10.1016/j.sbspro.2011.11.431.

[6] Sineace. (2018). Explicación de Estándares del Modelo de Acreditación para Programas de Estudios de Educación Superior Universitaria. Sistema Nacional de Evaluación, Acreditación y Certificación de la Calidad Educativa.

http://repositorio.sineace.gob.pe/repositorio/handle/sineace/5490.

[7] Alhassan I, Sowley E, Nalarb R, Kassim A. (2019). Analysis of Graduate Satisfaction and Experience with Higher Education Services in a Ghanaian University. European Journal of Educational Sciences, EJES 2018 Vol.5 No.4 ISSN 1857- 6036. http://dx.doi.org/10.19044/ejes.v5no4a2.

[8] Belash, O., Popov, M., Ryzhov, N., Ryaskov, Y., Shaposhnikov, S. \& Shestopalov, M. (2015). Research on university education quality assurance: Methodology and results of stakeholders' satisfaction monitoring. Procedia Social and Behavioral Sciences 214:344-358. https://doi.org/10.1016/j.sbspro.2015.11.658

[9] Temizer, L. \& Turkyilmaz, A. (2012). Implementation of Student Satisfaction index model in higher education institutions. Procedia-Social and Behavioral Sciences 46:3802-3806. https://doi.org/10.1016/j.sbspro.2012.06.150.

[10] Garzón CA. (2018). Modelo para el Seguimiento y Acompañamiento a Graduados (SAG), una visión holística de la gestión de la calidad de la educación superior. Educación Vol. XXVII, $\mathrm{N}^{\circ}$ 52:201-218. https://doi.org/10.18800/educacion.201801.011

[11] Azah, M., Fatihah, S., \& Abdul-Halim, I. (2012). Graduate students' perspectives on study environment based on exit. Canadian Center of Science and Education, 8(16). DOI: 10.5539/ass.v8n16p200

[12] Magid, M., Kamaruddin, N. \& Azirawani, N. (2009). Quality assurance in higher education institutions: Exist survey among University Putra Malaysia graduating students. International Education Studies, pp. 25-32. DOI: $10.5539 /$ ies.v2n1p25

[13] Othman, N. T. A., Misnon, R., Abdullah, S. R. S., Kofli, N. T., Kamarudin, S. K., \& Mohamad, A. B. (2011). Assessment of programme outcomes through exit survey of chemical/biochemical engineering students. Procedia Social and Behavioral Sciences, pp. 39-48. https://doi.org/10.1016/j.sbspro.2011.05.007

[14] Sineace. (2019). Estas son las 78 carreras universitarias acreditadas por el Sineace en Lima. Disponible en: https://www.sineace.gob.pe/estas-son-las78-carreras-universitarias-acreditadas-por-el-sineace-en-lima/

[15] Venezian E. y Chateauneuf R. (1997). Implicaciones del MERCOSUR para la formación agronómica universitaria. Primera Jornada Regional de Modernización de Facultades de Agronomía. CECAP-IICA. San José de Costa Rica. ISSN: 0534-5391; no. A1/SC-97-09.

[16] Sineace, (2016b). Estudio de oferta formativa y demanda laboral de personal operativo, técnico y profesional asociado a la gestión de riesgos de desastres y del cambio climático. Sistema Nacional de Evaluación, Acreditación y Certificación de la Calidad Educativa. http://bvpad.indeci.gob.pe/doc/pdf/esp/doc2656/doc2656-contenido.pdf

[17] Chirinos. (2016). Seguridad alimentaria Nutricional en Poblaciones Vulnerables de la Región Central del Perú. Editoral JOSIMPRESORES SAC. Huancayo. ISBN. 978-612-00-2291-7. 270 pp.

[18] CFZ. (1995). Plan Curricular de la Facultad de Zootecnia - 1995. Consejo de Facultad de Zootecnia - Universidad Nacional del Centro del Perú. Huancayo. Perú

[19] Landa, M. \& Ramírez, M. (2018). Design of a student satisfaction questionnaire for a professional level course under the inverted learning model. Revista Páginas de Educación. Vol. 11, Núm. 2.

[20] CFZ. (2002). Plan Curricular de la Facultad de Zootecnia - 2002. Consejo de Facultad de Zootecnia - Universidad Nacional del Centro del Perú. Huancayo. Perú.

[21] Ley Universitaria $N^{\circ} 30220$ (2014). Presidencia del Consejo de Ministros. Presidencia del Perú. MINEDU. http://www.minedu.gob.pe/reformauniversitaria/pdf/ley_universitaria.pdf 


\section{J. Castro et al. / Advances in Science, Technology and Engineering Systems Journal Vol. 5, No. 2, 166-173 (2020)}

[22] Ramírez, M. J, Reséndiz, M., y Reséndiz, M. E. (2017). Metodología de seguimiento de egresados para fortalecer la vinculación de la universidad con la sociedad. Revista Global de Negocios, 5(3), 99-111. https://ssrn.com/abstract $=2914540$.

[23] Aldana de Becerra, G. M., Morales-González, F. A., Aldana-Reyes, J. E., Sabogal-Camargo, F. J., Ospina, A. R. (2008). Seguimiento a egresados. Su importancia para las instituciones de educación superior. Teoría y praxis investigativa, 3(2), 61-65. Recuperado de https://dialnet.unirioja.es/servlet/articulo?codigo $=3701001$.

[24] Marulanda, J., Ortiz. E., Moratto, N., Arcila, A. (2010). Caracterización de egresados de la Universidad CES en las cohortes de 2003, 2005, 2007 y momento " 0 ". Revista CES Psicología 3(1), 50-63. http://revistas.ces.edu.co/index.php/psicologia/article/view/1156/745.

[25] Ivanaa, D. \& Dragan, M. (2014). Challenges and implications in assessing graduates' satisfaction in an international study program. Procedia Economics and Finance 16 pp. 104 - 109. https://doi.org/10.1016/S22125671(14)00780-1

[26] Uysal, F. (2015). Evaluation of the factors that determine quality in graduate education: Application of a satisfaction benchmarking approach. Procedia - Social and Behavioral Sciences 191 pp. 1034-1037. https://doi.org/10.1016/j.sbspro.2015.04.386

[27] Hanapi, Z. \& Nordin, M. S. (2014). Unemployment among Malaysia graduates: Graduates' attributes, lecturers' competency and quality of education. Procedia - Social and Behavioral Sciences 191 ( 2015 ) 1034

https://www.sciencedirect.com/science/article/pii/S1877042814012865. https://doi.org/10.1016/j.sbspro.2014.01.1269

[28] Cardona, M. M. \& Bravo, J. J. (2012). Service quality perceptions in higher education institutions: The case of a Colombian university. estud.gerenc. 28 (2012) 23-29. https://doi.org/10.1016/S0123-5923(12)70004-9.

[29] Uceda, J., y Sánchez-Canales, M. (2018). Rendición de cuentas y cómo hacerla. Kátedra. Cátedra UNESCO. http://catedraunesco.es/kathedra folder/Uceda18-

Rendicion_de_cuentas.pdf

[30] Rocha, M., Hernández, M., Ledo, M., Chávez, D. (2017). Satisfacción de egresados cubanos de la carrera de Medicina con la formación recibida. Curso 2015-2016, Cienfuegos. Medisur 15(4):509-515.

[31] Paredes MG. (2014). Nivel de satisfacción de estudiantes y egresados de la Universidad Nacional de Asunción. Revista Paraguaya de Educación, 1(4):57-69. ISSN 2305-1787

[32] Avendaño, C., Gutiérrez, K., Salgado, C., Alonso-Dos-Santos, M. (2016). Rendimiento Académico en Estudiantes de Ingeniería Comercial: Modelo por Competencias y Factores de Influencia. Formación Universitaria Vol. 9 No3. doi: 10.4067/S0718-50062016000300002. https://scielo.conicyt.cl/pdf/formuniv/v9n3/art02.pdf

[33] Fernández Rico, J. E., Fernández Fernández, S., Álvarez Suárez, A., y Martínez Camblor, P. (2007). Éxito Académico y Satisfacción de Estudiantes con la Enseñanza Universitaria, Relieve: 13(2).

[34] Salinas, A., Morales, J., Martínez, P. (2008). Satisfacción del estudiante y calidad universitaria: un análisis explicatorio en la unidad académica multidisciplinaria agronomía y ciencias de la Universidad Autónoma de Tamaulipas, México. Revista de Enseñanza Universitaria, N. ${ }^{031: 39-55 .}$ http://institucional.us.es/revistas/universitaria/31/4SalinasGuti.pdf

[35] Teixeira, S., Matos da Silva, J., Oom do Valle, P. (2014). A model of graduates' satisfaction and loyalty in tourism higher education: The role of employability. Journal of Hospitality, Leisure, Sport \& Tourism Education 16(2015):30-42. doi:10.1016/j.jhlste.2014.07.002.

[36] Espinoza, O., González, E., Loyola, J. (2018). Evaluación de la satisfacción de titulados de la carrera de psicología en Chile. Innovación Educativa. Vol. 18(76),171-192. http://www.scielo.org.mx/pdf/ie/v18n76/1665-2673-ie18-76-171.pdf

[37] de Vries, W., Vázquez-Cabrera, R., Ríos-Treto, D. (2013). Millonarios o malparados: ¿de qué depende el éxito de los egresados universitarios? Revista Iberoamericana de Educación Superior, vol. 4(9)3-20. https://doi.org/10.22201/iisue.20072872e.2013.9.80.

[38] Humburg, M., van der Velden, R., Verhagen, A. (2013). The Employability of Higher Education Graduates:The Employers' Perspective. European Commission. The Netherlands. https://www.researchgate.net/publication/265086055_The_Employability of_Higher_Education_Graduates_The_Employer's_Perspective.

[39] Eide, E., Hilmer, M., \& Showalter, M. (2015). Is it where you go or what you study? the relative influence of college selectivity and college major on earnings. Contemporary Economic Policy, 34(1), 37-46. doi:10.1111/coep.12115.
[40] Uquillas, S., Valarezo, C., Tituaña, L. (2019). El Sistema Académico Modular: Experiencias de la Universidad Nacional de Loja y Aprendizajes para la Innovación de la Universidad Ecuatoriana. Loja, Ecuador. https://unl.edu.ec/sites/default/files/archivo/2019 12/EL\%20SISTEMA\%20ACADEMICO\%20MODULAR.pdf

[41] Gutiérrez, Katiuska (2007). El papel de la prospectiva en las instituciones universitarias desde una perspectiva conceptual. Revista Informe de Investigaciones Educativas, XXI, http://biblo.una.edu.ve/ojs/index.php/IIE/article/view/547.

[42] Ruiz Ruiz, M. (2013). El futuro de la educación [superior]. Una reflexión entre la doxa y la episteme. Educación, 22(42), 7-27. Recuperado a partir de http://revistas.pucp.edu.pe/index.php/educacion/article/view/5289.

[43] Mulder M., Kupper H. (2006). The Future of Agricultural Education: The Case of the Netherlands. The Journal of Agricultural Education and Extension 12(2). DOI: 10.1080 / 13892240600861658.

[44] Tamboli, PM and Nene, YL. (2011). Revitalizing Higher Agricultural Education in India: Journey towards Excellence. Asian Agri-History Foundation, Secunderabad 500009, India. 316 pp. 